\title{
Thumb sign: acute epiglottitis
}

\author{
Mina Takata, ${ }^{1}$ Tatsuya Fujikawa, ${ }^{2}$ Rieko Goto ${ }^{3}$
}

${ }^{1}$ The Post-graduate Education Center, Mitoyo General Hospital, Kannonji, Kagawa, Japan

${ }^{2}$ Department of Internal Medicine, Mitoyo General Hospital, Kannonji, Kagawa, Japan

${ }^{3}$ Department of

Otorhinolaryngology, Head and Neck Surgery, Mitoyo General Hospital, Kannonji, Kagawa, Japan

Correspondence to Dr Tatsuya Fujikawa, tfujikawa-gi@umin.ac.jp

Accepted 13 May 2016

\section{DESCRIPTION}

A 65 -year-old man with a history of rectal cancer surgery presented to the emergency department, with fever and arthralgia in the neck, radiating to the shoulder, since the previous day. Although the origin of the fever was unknown, he was eventually admitted to the hospital because of disability and then treated with broad antibiotics. On day 3 , his symptoms became concentrated at the back of his throat. He experienced laboured breathing and respiratory distress. He was also drooling and his voice was muffled. Acute epiglottitis was suspected, and a lateral soft-tissue radiograph (figure 1A) and CT (figure 1B) showed a swollen epiglottis, which is termed as the 'thumb sign' (figure $1 \mathrm{~A}, \mathrm{~B}$; arrow), and narrowed vallecula (figure 1A, B; arrow head), consistent with acute epiglottitis.

After referring him to otolaryngology, an emergency surgical tracheostomy with local anaesthesia was performed under the diagnosis of acute epiglottitis. Two sets of blood cultures, collected immediately after hospitalisation, tested positive for Streptococcus gordonii, after several days, and antibiotics were de-escalated depending on the sensitivity of the culture report, and continued for 2 weeks. After verifying improved symptoms and diminished inflammation by repeated laryngoscopy, the tracheostomy site was closed and the patient discharged from the hospital, with no further events.

Acute epiglottitis is a cellulitis of the epiglottis and adjacent tissues that, without treatment, can rapidly progress to life-threatening conditions because of airway obstruction. ${ }^{1}$ Common symptoms of epiglottitis include sore throat, muffled voice, laboured breathing and respiratory distress. $^{1}$ Although laryngoscopy is the most accurate method to establish a diagnosis, lateral soft-tissue radiography of the neck also has a high sensitivity of $88 \% .^{2}$ Findings include swollen epiglottis (ie, thumb sign), thickened aryepiglottic folds and obliteration of the epiglottic vallecula. ${ }^{3}$

Epiglottitis is associated with a broad range of pathogens as well as non-infectious causes in adults. Among cases in which a pathogen is identified, Haemophilus influenzae, Streptococcus pneumoniae, Staphylococcus aureus and $\beta$-hemolytic streptococci are among the most common infective organisms. ${ }^{1}$

This patient did not exhibit the typical symptoms of acute epiglottitis but only had fever and neck-to-shoulder pain at the beginning of hospitalisation. Typical symptoms, such as respiratory distress or, particularly, drooling and muffled voice, ${ }^{1}$ appeared since hospital day 3 , and these symptoms then rapidly progressed. It is uncommon and noteworthy that not haemophilus influenzae type B, which deteriorates epiglottitis particularly rapidly, ${ }^{4}$ but $S$. gordonii, which is commonly known as an oral commensal bacteria, ${ }^{5}$ was assumed to be the causative pathogen and rapidly increased the risk of airway obstruction in this case.

It is important to perform an ear, nose and throat examination for fever of unknown origin and, although sometimes difficult, early recognition of the clinical condition and prompt airway intervention in cases of airway obstruction are crucial to avoid a possibly fatal outcome.
A

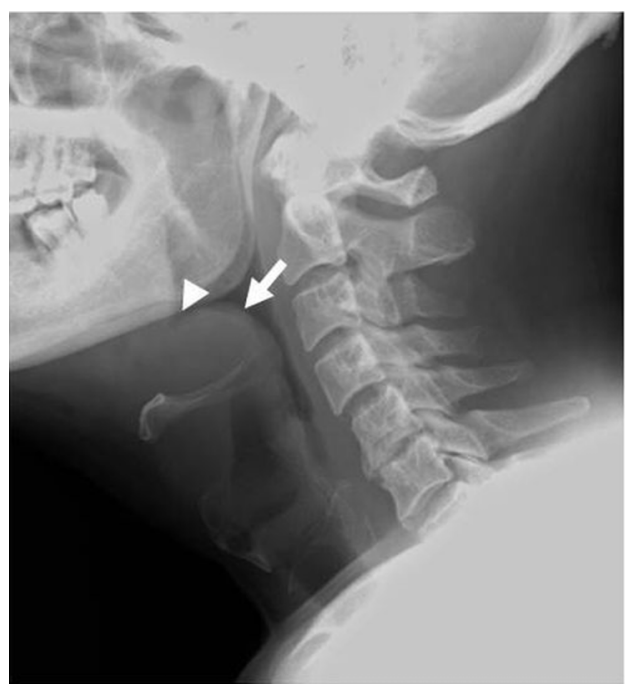

B

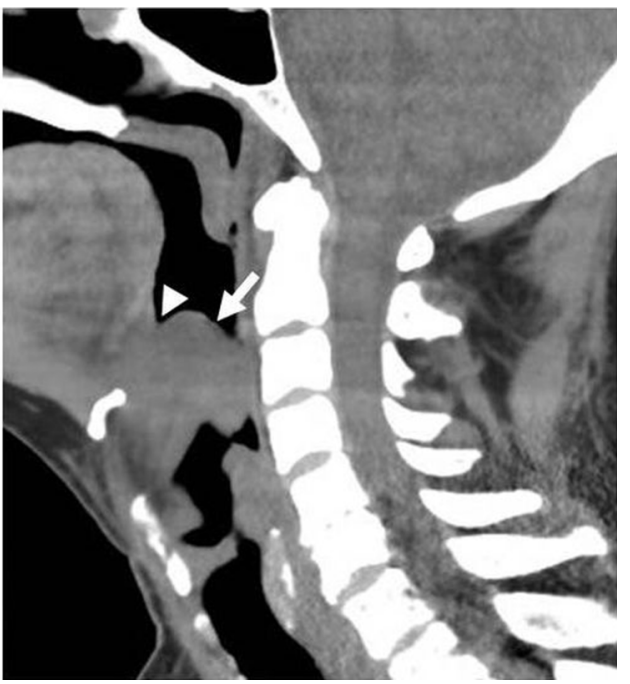

Figure 1 ( $A$ and $B$ ) Swollen epiglottis, termed as 'thumb sign' ( $A$ and $B$; arrow), and narrowed vallecula (A and B; arrow head), are consistent with acute epiglottitis. 


\section{Learning points}

- Epiglottitis is caused by inflammation and swelling of the epiglottis, and is usually caused by infection.

- Presenting features of epiglottitis include sore throat, muffled voice, laboured breathing and respiratory distress.

- It is important to perform an ear, nose and throat examination for fever of unknown origin and, although sometimes difficult, early recognition of the clinical condition and prompt airway intervention in cases of airway obstruction are crucial to avoid a possibly fatal outcome.

Acknowledgements All the authors would like to acknowledge Dr Tetsuya Nakamura for diagnostic imaging findings of this patient.
Contributors MT wrote the manuscript and contributed to the discussion. TF wrote and edited the manuscript, and contributed to the discussion. RG performed the surgery and contributed to the discussion.

Competing interests None declared.

\section{Patient consent Obtained.}

Provenance and peer review Not commissioned; externally peer reviewed.

\section{REFERENCES}

1 Li CJ, Aronowitz P. Sore throat, odynophagia, hoarseness, and a muffled, high-pitched voice. Cleve Clin J Med 2013;80:144-5.

2 Solomon P, Weisbrod M, Irish JC, et al. Adult epiglottitis: the Toronto Hospital experience. J Otolaryngol 1998;27:332-6.

3 Ragosta KG, Orr R, Detweiler MJ. Revisiting epiglottitis: a protocol—the value of lateral neck radiographs. J Am Osteopath Assoc 1997;97:227-9.

4 Mayo-Smith MF, Spinale JW, Donskey CJ, et al. Acute epiglottitis. An 18-year experience in Rhode Island. Chest 1995;108:1640-7.

5 Klein R, Dababneh AS, Palraj BR. Streptococcus gordonii prosthetic joint infection in the setting of vigorous dental flossing. BMJ Case Rep 2015;2015:pii: bcr2015210695.

Copyright 2016 BMJ Publishing Group. All rights reserved. For permission to reuse any of this content visit http://group.bmi.com/group/rights-licensing/permissions.

BMJ Case Report Fellows may re-use this article for personal use and teaching without any further permission.

Become a Fellow of BMJ Case Reports today and you can:

- Submit as many cases as you like

- Enjoy fast sympathetic peer review and rapid publication of accepted articles

- Access all the published articles

- Re-use any of the published material for personal use and teaching without further permission

For information on Institutional Fellowships contact consortiasales@bmjgroup.com

Visit casereports.bmj.com for more articles like this and to become a Fellow 